
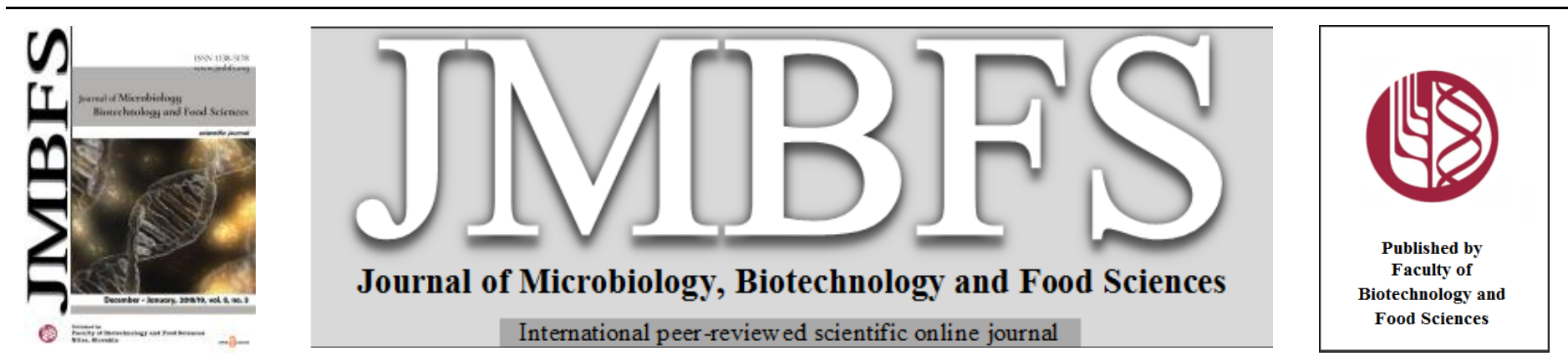

\title{
PHENOLIC COMPOUNDS AND ANTIRADICAL ACTIVITY IN TOKAJ WINES
}

\section{Daniel Bajčan ${ }^{* 1}$, Alena Vollmannovál, Marek Šnirc ${ }^{1}$, Július Árvay ${ }^{1}$, Ján Mezey ${ }^{2}$, Vladimír Šimansky ${ }^{3}$, Pavol Trebichalskýl, Radovan Stanovičl ${ }^{\text {, Mária Timorackál }}$}

\begin{abstract}
Address(es):
${ }^{1}$ Slovak University of Agriculture in Nitra, Faculty of Biotechnology and Food Sciences, Department of Chemistry, Tr. A. Hlinku 2, 94976 Nitra, Slovak Republic. ${ }^{2}$ Slovak University of Agriculture in Nitra, Faculty of Horticulture and Landscape Engineering, Department of fruit science, viticulture and enology, Tr. A. Hlinku 2, 94976 Nitra, Slovak Republic.

${ }^{3}$ Slovak University of Agriculture in Nitra, Faculty of Agrobiology and Food Resources, Department of pedology and geology, Tr. A. Hlinku 2, 94976 Nitra, Slovak Republic.
\end{abstract}

*Corresponding author: bajcan@gmail.com

doi: 10.15414/jmbfs.2018-19.8.3.955-959

\section{ARTICLE INFO}

Received 27. 7. 2018

Revised 10. 10. 2018

Accepted 11. 10. 2018

Published 1. 12. 2018

Regular article

open $\bigodot_{\text {ACCESS }}$

\begin{abstract}
Eighteen wine samples (varieties - Lindenblaetrige, Yellow Muscat and Furmint), originated from Slovak and Hungarian part of Tokaj wine region, were analyzed for the content of total polyphenols, content of total flavonoids and antiradical activity by UV-VIS spectrometry. Our results showed that Slovak Tokaj wines had higher content of healthy useful phenolic and flavonoid compounds (all three varieties) and higher value of antiradical activity (two varieties) than Hungarian Tokaj wines. The highest total phenolic and total flavonoid contents we found out in wines variety Yellow Muscat. The highest value of antiradical activity was found out in wines variety Lindenblaetrige. Our results confirmed very strong linear correlations between all three analysed parameters (TPC, TFC and AA): TPC and TFC ( $r=0.867), A A$ and TPC $(r=0.836)$, resp. TFC and AA $(r=0.766)$.
\end{abstract}

Keywords: antioxidants, antiradical activity, flavonoids, polyphenols, Tokaj, wine

\section{INTRODUCTION}

In recent years, much information has appeared about the role of oxidative stress in the development of a number of serious illnesses, such as certain cancers, cardiovascular diseases and age-related degenerative diseases, and about the possible therapeutic value of antioxidants against these illnesses. The terms antioxidant and free radical are popular expressions used by scientists, nutritionists and other healthcare professionals. Free radicals are chemica species, compounds and/or elements with one or two unpaired electrons in their outer layer, which can be created in a multiple ways. They can be exogenic (e.g. ultraviolet radiation, xenobiotics and infections) or endogenic. Antioxidants are molecules which can interact with free radicals and break the chain reaction before vital molecules are damaged. A lack of antioxidant or an overproduction in free radicals can lead to an imbalance between the oxidant and antioxidant system (Barhé and Tchouya, 2016; Evans, 2007; Guerci et al., 2001).

Polyphenols are important constituents of plant cells, known for their multiple physiological roles including screening solar radiation and scavenging various free radicals (Berli et al., 2008; Pietta, 2000; Torel et al., 1986). Wine polyphenolic substances are usually subdivided into two groups: flavonoids and non-flavonoid compounds. The flavonoids have a common core, the flavane nucleus, consisting of two benzene rings (A and B) linked by an oxygen containing pyran ring (C) (C6C3C6). To date, over 3000 flavonoids have been identified. These can mainly be found in the pigments in flowers or in leaves (Marfak, 2003; Timoracká, 2010).

In the last few decades an intensive investigations underway to characterize the beneficial effects of moderate wine consumption. Wine is very rich source of polyphenols, such as catechins, epicatechins, quercetin, rutin, myricetin, anthocyanins, phenolic acids (gallic acid, caffeic acid, p-coumaric acid, etc.), trans-resveratrol and many others polyphenols and compounds. Many of these compounds have been reported to have multiple biological activities, including cardioprotective, anti-carcinogenic, antiviral, antidegenerative and antibacterial properties (Bystrická et al., 2014; King et al., 2006; Santos-Buelga and Scalbert, 2000).

In previous studies, we described some antioxidant properties, such as total polyphenol content, total flavonoid content, total anthocyanin content and antioxidant activity of the Slovak monovarietal red (Bajčan et al., 2012a,b;
2015, 2016) and white (Bajčan et al., 2017) wines originating in different vineyard areas, excluding Tokaj wine region.

Tokaj wine region lies in the Lower Zemplín in the south-eastern corner of Slovakia. It follows a wine region, most of which is located in Hungary. This area is also the smallest, but most attractive wine-growing region of Slovakia. It consists of the southern slopes of the Zemplín hills planted with vines after two millennia. Tokaj wine area is one of the few areas in the world where the grown grapes for the production of natural sweet wines. On the specific and unique taste of Tokaj wine has its share of both heavy sunlight, but also soil of volcanic origin. Very important is role of weather, long sunny autumn, which will enable aged berries attacked noble Botrytis cinerea mould, and dried berries that remain cibeba-raisins, without which the Tokaj wine quality can not be manufactured. Under these specific environmental conditions, pathogenesis is severely constrained, resulting in partial fruit dehydration and chemical transformation. These noble-rotted grapes produce some of the most sought-after, delicious, and expensive dessert wines (Farkaš, 1983; Felšöciová et al., 2015; Jackson, 2014).

Numerous papers have been published on red and white wines but relatively few data are available on Tokay varietal non-botrytized wines. So we analyzed some of the abovementioned properties in the monovarietal wines typical for Tokaj wine region (Lindenblaetrige - Lipovina /Slovak nomenclature/ or Hárslevelü /Hungarian nomenclature/; Yellow Muscat - Muškát žltý /Slovak nom./ or Sárgamuskotály /Hungarian nom./; Furmint - Furmint/Slovak and Hungarian nom./) here, and compared them with those of selected white wine samples originating from various sources.

\section{MATERIAL AND METHODS}

\section{Chemicals and instruments}

All analysed parameters - total polyphenol content, total flavonoid content and antiradical activity in wines were analyzed by UV/VIS spectrophotometry (spectrophotometer Shimadzu UV/VIS - 1240, Shimadzu, Japan). The chemicals used for all analysis were: Folin-Ciocalteau reagent, monohydrate of gallic acid p.a., anhydrous natrium carbonate p.a., aluminum chloride p.a., sodium nitrite p.a., sodium hydroxide p.a., catechin hydrate $98 \%$, methanol p.a., 2,2-diphenyl-1- 
picrylhydrazyl (DPPH) radical p.a., Trolox (pure) /Sigma-Aldrich Chemie and Merck KGaA, Germany/.

\section{Samples}

Analysed, bottled, Tokaj wines - Lindenblaetrige (LB), Yellow Muscat (YM), resp. Furmint (FT) and their characteristics are mentioned in Table 1. Wine samples with origin in Tokaj vineyard area were purchased in retail network, to provide that analysed wine samples would have the same properties as wines that are consumed by common consumers (properties of wine affected by various factors, such as period and conditions of storage or distribution of wine).

Table 1 Characteristics of analysed Tokaj wine samples

\begin{tabular}{|c|c|c|c|c|c|}
\hline Sample & Variety & Producer & Country & Vintage & Wine type \\
\hline LB-S-1 & \multirow{6}{*}{ Lindenblaetrige } & Tokaj\&CO, s.r.o.,Malá Tŕňa & \multirow{3}{*}{ Slovakia } & 2016 & semisweet \\
\hline LB-S-2 & & J\&J Ostožovič, Vel'ká Tŕňa & & 2015 & semidry \\
\hline LB-S-3 & & Zlatý strapec - Anna Nagyová, Viničky & & 2013 & semisweet \\
\hline LB-H-1 & & BORANAL Kft., Sárospatak & \multirow{3}{*}{ Hungary } & 2016 & semisweet \\
\hline LB-H-2 & & Disznókő Szőlőbirtok és Pincészet, Mezőzombor & & 2015 & dry \\
\hline LB-H-3 & & Ungvár-Pince Kft., Sátoraljaújhely & & 2016 & semisweet \\
\hline YM-S-1 & \multirow{6}{*}{ Yellow Muscat } & Tokaj\&CO, s.r.o.,Malá Tŕňa & \multirow{3}{*}{ Slovakia } & 2016 & semisweet \\
\hline YM -S-2 & & J\&J Ostožovič, Vel'ká Tŕňa & & 2015 & semidry \\
\hline YM -S-3 & & Zlatý strapec - Anna Nagyová, Viničky & & 2013 & semisweet \\
\hline YM -H-1 & & BORANAL Kft., Sárospatak & \multirow{3}{*}{ Hungary } & 2015 & semisweet \\
\hline YM -H-2 & & Disznókő Szőlőbirtok és Pincészet, Mezőzombor & & 2015 & semisweet \\
\hline YM -H-3 & & Ungvár-Pince Kft., Sátoraljaújhely & & 2016 & semisweet \\
\hline FT-S-1 & \multirow{6}{*}{ Furmint } & Tokaj\&CO, s.r.o.,Malá Tŕňa & \multirow{3}{*}{ Slovakia } & 2015 & dry \\
\hline FT-S-2 & & J\&J Ostožovič, Vel'ká Tŕňa & & 2014 & semidry \\
\hline FT-S-3 & & Zlatý strapec - Anna Nagyová, Viničky & & 2013 & dry \\
\hline FT-H-1 & & BORANAL Kft., Sárospatak & \multirow{3}{*}{ Hungary } & 2016 & semisweet \\
\hline FT-H-2 & & Disznókő Szőlőbirtok és Pincészet, Mezőzombor & & 2015 & dry \\
\hline FT-H-3 & & Ungvár-Pince Kft., Sátoraljaújhely & & 2016 & semisweet \\
\hline
\end{tabular}

\section{Sample analysis}

Total polyphenol content (TPC) was determined by modified method of Singleton and Rossi (1965). $0.1 \mathrm{~mL}$ of wine sample was pipetted into $50 \mathrm{~mL}$ volumetric flask and diluted with $5 \mathrm{~mL}$ of distilled water. To diluted mixture 2.5 $\mathrm{mL}$ Folin-Ciocalteau reagent was added and after 3 minutes $7.5 \mathrm{~mL}$ of $20 \%$ solution of $\mathrm{Na}_{2} \mathrm{CO}_{3}$ was added. Then the sample was filled with distilled water to volume $50 \mathrm{~mL}$ and after mixing left at the laboratory temperature for 2 hours. By the same procedure the blank and calibration solutions of gallic acid were prepared. Absorbance of samples solutions was measured against blank at 765 $\mathrm{nm}$. Total polyphenol (TP) content in wines was calculated as amount of gallic acid equivalent (GAE) in mg per 1 litre of wine.

Total flavonoid content (TFC) was assessed by aluminum chloride method (Chang et al., 2002). $1 \mathrm{ml}$ of wine sample and $4 \mathrm{ml}$ of deionized water were added to a $10 \mathrm{ml}$ volumetric flask. $5 \mathrm{~min}$ after adding $0.3 \mathrm{ml}$ of $5 \%$ sodium nitrite, $0.3 \mathrm{ml}$ of $10 \%$ aluminum chloride was added. $2 \mathrm{ml}$ of sodium hydroxide with concentration $1 \mathrm{~mol} / \mathrm{L}$ was added to the reaction mixture after $6 \mathrm{~min}$ incubation. The final volume was immediately made up to $10 \mathrm{ml}$ with deionized water. The absorbance of the solution was measured at $510 \mathrm{~nm}$ against blank solution. The content of total flavonoids (TF) in wine samples was calculated as amount of catechin equivalent (CE) in mg per 1 litre of wine.

Antiradical activity (AA) was assessed by method of Brand-Williams $\boldsymbol{e t}$ al. (1995) using of DPPH (2,2-diphenyl-1-picrylhydrazyl) radical. Absorbance was read at $515.6 \mathrm{~nm}$ and antioxidant effectiveness was expressed as \% inhibition of DPPH (quantitative ability of tested compound to remove in certain period a part of DPPH radical) and also as Trolox equivalent calculated from calibration curve. All chemical analyses were performed as four parallels.

\section{Statistical analysis}

The Shapiro-Wilk test showed that the data were not normally distributed. Therefore, nonparametric Kruskal-Wallis test was conducted in order to obtain statistically significant information about the differences between the tested samples and Spearman correlation was performed to investigate the relationship between the tested variables. All calculations were performed using MS Excel 2016 and XLSTAT (Addinsoft, 2014).

\section{RESULTS AND DISCUSSION}

All studied parameters - the content of total polyphenols, the content of tota flavonoids and antiradical activity of Tokaj wines are described in Table 2, 3 and

Total polyphenol content in analysed wines variety Lindenblaetrige was in range from 287.6 to $540.3 \mathrm{mg}$ GAE/L. Average content of TP in all wines variety LB was $411.3 \mathrm{mg} \mathrm{GAE} / \mathrm{L}$. Slovak wines variety LB had approximately a half higher values of TPC (average content $489.8 \mathrm{mg}$ GAE/L) than Hungarian wines (average content $332.7 \mathrm{mg} \mathrm{GAE} / \mathrm{L}$ ) /Table $2 /$. It is very difficult to compare our results with the results of other authors because none of them have expressed the total content of polyphenols as the equivalent of gallic acid. Eftimova (2016) found that the content of total polyphenols in Tokaj wine - Lindenblaetrige originating in Slovakia was $182.6 \mathrm{mg}$ of quercetin per liter.

Total flavonoid content in analysed wines variety Lindenblaetrige was in range from 31.0 to $101.2 \mathrm{mg} \mathrm{CE} / \mathrm{L}$. Average content of TF in all wines variety LB was $65.4 \mathrm{mg} \mathrm{CE} / \mathrm{L}$. Slovak wines variety LB had more than 2 times higher values of TFC (average content $89.3 \mathrm{mg} \mathrm{CE} / \mathrm{L}$ ) than Hungarian wines (average content $41.5 \mathrm{mg} \mathrm{CE} / \mathrm{L}$ ). Until now the content of total flavonoids in Tokaj wines has not been investigated.

Antiradical activity in analysed wines variety Lindenblaetrige was in range from $31.2 \%$ inhibition of DPPH $\left(0.354 \mathrm{mmol}\right.$ Trolox. $\left.\mathrm{L}^{-1}\right)$ to $65.6 \%$ inhib. of DPPH $\left(0.768 \mathrm{mmol}\right.$ Trolox. $\left.\mathrm{L}^{-1}\right)$. Average value of AA in all wines variety LB was 49.5 $\%$ inhib. of DPPH $\left(0.568 \mathrm{mmol}\right.$ Trolox. $\left.\mathrm{L}^{-1}\right)$. Slovak wines variety LB had much higher values of AA (average value $57.5 \%$ inhib. of DPPH, resp. $0.664 \mathrm{mmol}$ Trolox. $\mathrm{L}^{-1}$ ) than Hungarian wines (average value $41.5 \%$ inhib. of DPPH, resp $0.471 \mathrm{mmol}$ Trolox. $\left.\mathrm{L}^{-1}\right)$. Our results are very similar to results reported by Eftimova (2016), who found that antiradical activity in Tokaj wine Lindenblaetrige originating in Slovakia was $53.5 \%$ inhib. of DPPH.

Gained results exert statistically significant differences (at significance level $\mathrm{P}<0.05$ ) between values of TPC, TFC and AA in wines variety LB made in Slovakia and Hungary. 
Table 2 The content of total polyphenols, content of total flavonoids and antiradical activity in analysed wines variety Lindenblaetrige

\begin{tabular}{|c|c|c|c|c|}
\hline Sample & $\begin{array}{c}\text { TPC } \\
\left({\left.\mathrm{mg} \mathrm{GAE} . L^{-1}\right)}^{-}\right.\end{array}$ & $\begin{array}{c}\text { TFC } \\
\left(\mathrm{mg} \mathrm{CE} \cdot \mathrm{L}^{-1}\right)\end{array}$ & $\begin{array}{c}\mathbf{A A} \\
(\% \text { inhib. DPPH })\end{array}$ & $\begin{array}{c}\mathbf{A A} \\
\left(\mathrm{mmol} \text { Trolox. } \mathrm{L}^{-1}\right)\end{array}$ \\
\hline LB-S-1 & $491.8 \pm 2.6$ & $76.9 \pm 1.3$ & $51.6 \pm 1.1$ & $0.588 \pm 0.014$ \\
\hline LB-S-2 & $437.2 \pm 5.3$ & $101.2 \pm 0.8$ & $55.4 \pm 1.1$ & $0.635 \pm 0.014$ \\
\hline LB-S-3 & $540.3 \pm 11.1$ & $89.7 \pm 0.7$ & $65.6 \pm 0.8$ & $0.768 \pm 0.010$ \\
\hline Average LB-SVK & $489.8 \pm 60.9^{a}$ & $89.3 \pm 14.4^{a}$ & $57.5 \pm 8.3^{a}$ & $0.664 \pm 0.106^{a}$ \\
\hline LB-H-1 & $420.8 \pm 2.6$ & $56.8 \pm 0.8$ & $50.6 \pm 1.3$ & $0.576 \pm 0.016$ \\
\hline LB-H-2 & $289.6 \pm 2.6$ & $36.6 \pm 0.8$ & $42.7 \pm 0.6$ & $0.484 \pm 0.007$ \\
\hline LB-H-3 & $287.6 \pm 4.4$ & $31.0 \pm 1.0$ & $31.2 \pm 0.6$ & $0.354 \pm 0.007$ \\
\hline Average LB-HUN & $332.7 \pm 78.7^{b}$ & $41.5 \pm 15.2^{b}$ & $41.5 \pm 11.5^{b}$ & $0.471 \pm 0.131^{b}$ \\
\hline Total average $L B$ & $411.3 \pm 99.7$ & $65.4 \pm 27.7$ & $49.5 \pm 13.6$ & $0.568 \pm 0.163$ \\
\hline
\end{tabular}

Legend: SVK - Slovakia, HUN - Hungary, LB - Lindenblaetrige, TPC - total polyphenol content, TFC - total flavonoid content, AA - antiradical activity.

Values of TPC, TFC and AA are expressed as arithmetic average \pm standard deviation,

a-b Values with different letters denote significant differences $(\mathrm{P}<0.05)$ among countries.

Total polyphenol content in analysed wines variety Yellow Muscat ranged from 267.8 to $568.3 \mathrm{mg}$ GAE/L. Average content of TP in all wines variety YM was $420.5 \mathrm{mg}$ GAE/L. Slovak wines variety YM had much higher values of TPC (average content $525.6 \mathrm{mg} \mathrm{GAE} / \mathrm{L}$ ) than Hungarian wines (average content 315.4 $\mathrm{mg} \mathrm{GAE} / \mathrm{L}$ ) /Table 3/. Other researchers reported diverse values of total polyphenol content in Tokaj wines variety Yellow Muscat: Eftimova (2016) $252.3 \mathrm{mg}$ of quercetin per liter and Lugasi and Hovari (2003) - $250 \mathrm{mg}$ of catechin per liter.

Total flavonoid content in analysed wines variety Yellow Muscat was in range from 30.6 to $169.1 \mathrm{mg}$ CE/L. Average content of TF in all wines variety YM was $83.0 \mathrm{mg} \mathrm{CE} / \mathrm{L}$. Slovak wines variety YM had more than 2 times higher values of TFC (average content $119.4 \mathrm{mg} \mathrm{CE} / \mathrm{L}$ ) than Hungarian wines (average content $46.7 \mathrm{mg} \mathrm{CE} / \mathrm{L})$.
Antiradical activity in analysed wines variety Yellow Muscat ranged from $26.6 \%$ inhibition of DPPH (0.302 mmol Trolox. $\left.\mathrm{L}^{-1}\right)$ to $67.4 \%$ inhib. of DPPH $(0.793$ mmol Trolox. $\left.\mathrm{L}^{-1}\right)$. Average value of $\mathrm{AA}$ in all wines variety $\mathrm{YM}$ was $47.2 \%$ inhib. of DPPH (0.542 mmol Trolox. $\left.\mathrm{L}^{-1}\right)$. Slovak wines variety YM had much higher values of AA (average value $58.8 \%$ inhib. of DPPH, resp. $0.680 \mathrm{mmo}$ Trolox. $\mathrm{L}^{-1}$ ) than Hungarian wines (average value $35.7 \%$ inhib. of DPPH, resp $0.404 \mathrm{mmol}$ Trolox. $\left.\mathrm{L}^{-1}\right)$. Our results are quite similar to the results reported by Eftimova (2016), who found that antiradical activity in Tokaj wine - Yellow Muscat originating in Slovakia was $63.8 \%$ inhib. of DPPH.

Gained results confirmed statistically significant differences (at significance level $\mathrm{P}<0.05)$ between the TPC, TFC and AA values in wines variety YM produced in Slovakia and Hungary.

Table 3 The content of total polyphenols, content of total flavonoids and antiradical activity in analysed wines variety Yellow Muscat

\begin{tabular}{|c|c|c|c|c|}
\hline Sample & $\begin{array}{c}\text { TPC } \\
\left(\mathrm{mg} \mathrm{GAE} . L^{-1}\right)\end{array}$ & 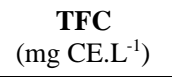 & $\begin{array}{c}\text { AA } \\
(\% \text { inhib. DPPH })\end{array}$ & $\underset{\left(\operatorname{mmol} \text { Trolox. } L^{-1}\right)}{\mathbf{A A}}$ \\
\hline YM-S-1 & $513.7 \pm 9.3$ & $99.5 \pm 1.3$ & $57.6 \pm 0.8$ & $0.662 \pm 0.010$ \\
\hline YM -S-2 & $568.3 \pm 13.3$ & $169.1 \pm 1.3$ & $67.4 \pm 0.6$ & $0.793 \pm 0.007$ \\
\hline YM -S-3 & $494.8 \pm 10.6$ & $89.6 \pm 1.5$ & $51.4 \pm 0.6$ & $0.586 \pm 0.007$ \\
\hline Average YM-SVK & $525.6 \pm 43.4^{a}$ & $119.4 \pm 47.0^{a}$ & $58.8 \pm 9.5^{a}$ & $0.680 \pm 0.122^{a}$ \\
\hline YM -H-1 & $345.0 \pm 14.6$ & $53.2 \pm 0.8$ & $38.4 \pm 0.5$ & $0.435 \pm 0.006$ \\
\hline YM -H-2 & $333.3 \pm 12.0$ & $56.4 \pm 1.8$ & $42.0 \pm 0.6$ & $0.476 \pm 0.007$ \\
\hline YM -H-3 & $267.8 \pm 4.0$ & $30.6 \pm 1.0$ & $26.6 \pm 0.8$ & $0.302 \pm 0.010$ \\
\hline Average YM-HUN & $315.4 \pm 45.6^{b}$ & $46.7 \pm 15.2^{b}$ & $35.7 \pm 9.1^{b}$ & $0.404 \pm 0.103^{b}$ \\
\hline Total average YM & $420.5 \pm 118.6$ & $83.0 \pm 54.7$ & $47.2 \pm 16.1$ & $0.542 \pm 0.194$ \\
\hline
\end{tabular}

Legend: SVK - Slovakia, HUN - Hungary, YM - Yellow Muscat, TPC - total polyphenol content, TFC - total flavonoid content, AA - antiradical activity.

Values of TPC, TFC and AA are expressed as arithmetic average \pm standard deviation,

${ }^{\mathrm{a}-\mathrm{b}}$ Values with different letters denote significant differences $(\mathrm{P}<0.05)$ among countries.

Total polyphenol content in analysed wines variety Furmint was in range from 241.8 to $457.7 \mathrm{mg} \mathrm{GAE} / \mathrm{L}$. Average content of TP in all wines variety FT was $359.3 \mathrm{mg}$ GAE/L. Slovak wines variety FT had much higher values of TPC (average content $405.3 \mathrm{mg} \mathrm{GAE} / \mathrm{L}$ ) than Hungarian wines (average content 313.3 mg GAE/L) /Table 4/. Other researchers reported diverse values of total polyphenol content in Tokaj wines variety Furmint: Eftimova (2016) - $240.5 \mathrm{mg}$ of quercetin per liter and Sato et al. (1996) from 312.5 to $373.2 \mathrm{ppm}$.

Total flavonoid content in analysed wines variety Furmint was in range from 28.3 to $117.6 \mathrm{mg} \mathrm{CE} / \mathrm{L}$. Average content of TF in all wines variety FT was $67.7 \mathrm{mg}$ $\mathrm{CE} / \mathrm{L}$. Slovak wines variety FT had about 2 times higher values of TFC (average content $88.5 \mathrm{mg} \mathrm{CE} / \mathrm{L}$ ) than Hungarian wines (average content $46.9 \mathrm{mg} \mathrm{CE} / \mathrm{L}$ ).
Antiradical activity in analysed wines variety Furmint was in range from $27.1 \%$ inhibition of DPPH $\left(0.308 \mathrm{mmol}\right.$ Trolox. $\left.\mathrm{L}^{-1}\right)$ to $63.2 \%$ inhib. of DPPH $(0.735$ mmol Trolox. $\left.\mathrm{L}^{-1}\right)$. Average value of AA in all wines variety FT was $47.0 \%$ inhib. of DPPH $\left(0.538\right.$ mmol Trolox. $\left.\mathrm{L}^{-1}\right)$. Slovak wines variety FT had a slightly higher values of AA (average value $48.5 \%$ inhib. of DPPH, resp. $0.552 \mathrm{mmo}$ Trolox. $\mathrm{L}^{-1}$ ) than Hungarian wines (average value $45.5 \%$ inhib. of DPPH, resp. 0.523 mmol Trolox. $\mathrm{L}^{-1}$ ). Eftimova (2016) found out similar value of antiradical activity in Tokaj wine - Furmint originating in Slovakia $-52.8 \%$ inhib. of DPPH.

Gained results exert statistically significant differences (at significance level $\mathrm{P}<0.05$ ) between values of TPC, resp. TFC (but not AA) in wines variety FT made in Slovakia and Hungary. 
Table 4 The content of total polyphenols, content of total flavonoids and antiradical activity in analysed wines variety Furmint

\begin{tabular}{|c|c|c|c|c|}
\hline Sample & $\begin{array}{c}\text { TPC } \\
\left(\mathrm{mg} \mathrm{GAE} . \mathrm{L}^{-1}\right)\end{array}$ & $\begin{array}{c}\text { TFC } \\
\left(\mathrm{mg} \mathrm{CE} . \mathrm{L}^{-1}\right)\end{array}$ & $\underset{(\% \text { inhib. DPPH })}{\mathbf{A A}}$ & $\begin{array}{c}\mathbf{A A} \\
\left(\operatorname{mmol} \text { Trolox. } L^{-1}\right)\end{array}$ \\
\hline FT-S-1 & $457.7 \pm 6.7$ & $117.6 \pm 1.0$ & $52.6 \pm 0.7$ & $0.600 \pm 0.009$ \\
\hline FT-S-2 & $383.9 \pm 13.3$ & $64.7 \pm 0.8$ & $44.0 \pm 1.1$ & $0.499 \pm 0.014$ \\
\hline FT-S-3 & $374.3 \pm 10.6$ & $83.1 \pm 1.0$ & $49.0 \pm 0.5$ & $0.557 \pm 0.006$ \\
\hline Average FT-SVK & $405.3 \pm 49.3^{a}$ & $88.5 \pm 31.3^{a}$ & $48.5 \pm 5.1^{a}$ & $0.552 \pm 0.060^{a}$ \\
\hline FT-H-1 & $356.6 \pm 6.7$ & $60.3 \pm 0.5$ & $46.2 \pm 0.7$ & $0.525 \pm 0.009$ \\
\hline FT-H-2 & $341.6 \pm 10.6$ & $52.1 \pm 0.8$ & $63.2 \pm 0.9$ & $0.735 \pm 0.011$ \\
\hline FT-H-3 & $241.8 \pm 10.6$ & $28.3 \pm 0.5$ & $27.1 \pm 0.9$ & $0.308 \pm 0.011$ \\
\hline Average FT-HUN & $313.3 \pm 67.8^{b}$ & $46.9 \pm 18.9^{b}$ & $45.5 \pm 21.3^{a}$ & $0.523 \pm 0.252^{a}$ \\
\hline Total average FT & $359.3 \pm 85.2$ & $67.7 \pm 35.2$ & $47.0 \pm 14.2$ & $0.538 \pm 0.168$ \\
\hline Total average Tokaj & $397.5 \pm 89.3$ & $72.0 \pm 35.9$ & $47.9 \pm 12.1$ & $0.549 \pm 0.145$ \\
\hline
\end{tabular}

Legend: SVK - Slovakia, HUN - Hungary, FT - Furmint, TPC - total polyphenol content, TFC - total flavonoid content, AA - antiradical activity.

Values of TPC, TFC and AA are expressed as arithmetic average \pm standard deviation,

a-b Values with different letters denote significant differences $(\mathrm{P}<0.05)$ among countries

Total polyphenol content in all analysed Tokaj wines ranged from 241.8 to 568.3 $\mathrm{mg}$ GAE/L. Average content of TP in all Tokaj wines was $397.5 \mathrm{mg} \mathrm{GAE} / \mathrm{L}$ (Tab. 4). According to the average value of TPC an order for Tokaj varietal wines could be as following: wines Yellow Muscat $\left(420.5 \mathrm{mg}\right.$ GAE. $\left.\mathrm{L}^{-1}\right)>$ wines Lindenblaetrige (411.3 mg GAE.L $\left.\mathrm{L}^{-1}\right)>$ wines Furmint (359.3 mg GAE.L $\mathrm{L}^{-1}$ ). When comparing the average TPC of Tokaj wines with other white monovarietal wines, we can conclude that Tokaj wines have a significantly higher (about 20 $50 \%$ ) total content of phenolic substances.

Total flavonoid content in all analysed Tokaj wines ranged from 28.3 to 169.1 $\mathrm{mg} \mathrm{CE} / \mathrm{L}$. Average content of TF in all Tokaj wines was $72.0 \mathrm{mg} \mathrm{CE} / \mathrm{L}$. According to the average value of TFC an order for Tokaj varietal wines could be as following: wines Yellow Muscat $\left(83.0 \mathrm{mg}\right.$ CE. $\left.\mathrm{L}^{-1}\right)>$ wines Furmint (67.7 $\mathrm{mg}$ CE. $\left.\mathrm{L}^{-1}\right)>$ wines Lindenblaetrige (65.4 mg CE. $\left.\mathrm{L}^{-1}\right)$. When comparing the average TFC of Tokaj wines with other white monovarietal wines, we can conclude that Tokaj wines have comparable value of the total flavonoid content. Antiradical activity in all analysed Tokaj wines ranged from 26.6 to $67.4 \%$ inhibition of DPPH $\left(0.302-0.793 \mathrm{mmol}\right.$ Trolox. $\left.\mathrm{L}^{-1}\right)$. Average value of AA in al Tokaj wines was $47.9 \%$ inhibition of DPPH $\left(0.549 \mathrm{mmol}\right.$ Trolox. $\left.\mathrm{L}^{-1}\right)$. According to the average value of $\mathrm{AA}$ an order for Tokaj varietal wines could be as following: wines Lindenblaetrige (49.5\% inhib. DPPH) > wines Yellow Muscat $(47.2 \%$ inhib. DPPH) $>$ wines Furmint (47.0\% inhib. DPPH). When comparing the average AA value of Tokaj wines with other white monovarietal wines, we can conclude that Tokaj wines have a significantly higher (about $10-50 \%$ ) value of AA. Staško et al. (2006), Fikselová et al. (2010) also concluded in their works, that Tokay wines showed a very good scavenging ability, positioned between white and red wines.

The statistical evaluation of the obtained results confirmed strong positive relationship at significance level $\mathrm{P}<0.001$ between all 3 studied parameters: TPC and TFC $(r=0.867)$, AA and TPC $(r=0.836)$, resp. TFC and AA $(r=0.766)$. This was consistent with many other articles in the literature, which also reported strong positive relationship between the total phenols, total flavonoids and antiradical properties of wines (Chircu Brad et al., 2012; Li et al., 2009; Ma et al., 2014 and Minussi et al., 2003)

\section{CONCLUSION}

The phenolic, resp. flavonoid content and antiradical properties of Tokaj wines (varieties: Lindenblaetrige, Yellow Muscat and Furmint) produced in Slovak and Hungarian parts of Tokaj vineyard area were evaluated in the present study. The highest total phenolic and total flavonoid contents were found out in wines variety Yellow Muscat. On the other hand, the highest value of antiradical activity was found out in wines variety Lindenblaetrige. Statistical analysis of the measured data showed that Slovak Tokaj wines had significantly higher content of healthy useful phenolic compounds and significantly higher value of antiradical activity than Hungarian Tokaj wines.

Acknowledgments: The work was supported by the Slovak Science Foundation VEGA (Grant no. 1/0139/17 and Grant no. 1/0114/18).

\section{REFERENCES}

ADDINSOFT. 2014. XLSTAT, Analyse de données et statistique avec MS Excel. Addinsoft, NY, USA

BAJČAN, D., ČÉRYOVÁ, S., TOMÁS̆, J. 2012a. Antioxidant properties of the bestselling Slovak red wines. Journal of Microbiology, Biotechnology and Food Sciences, 1(4), 455-465.

BAJČAN, D., ČÉRYOVÁ, S., T`OTH, T. 2012b. Phenolic compounds and antioxidant activity of monovarietal red wines produced in Limbach region.
Journal of Microbiology, Biotechnology and Food Sciences, 1(special issue), 868-875.

BAJČAN, D., ŠIMANSKÝ, V., TÓTH, T., ÁRVAY, J. 2015. Colour, phenolic content and antioxidant activity of the Slovak Alibernet red wine samples Journal of Microbiology, Biotechnology and Food Sciences, 4(special issue 3), 58. https://doi.org/10.15414/jmbfs.2015.4.special3.5-8

BAJČAN, D., VOLLMANNOVÁ, A., ŠIMANSKÝ, V., BYSTRICKÁ, J., TREBICHALSKÝ, P., ÁRVAY, J., CZAKO, P. 2016. Antioxidant activity, phenolic content and colour of the Slovak Cabernet Sauvignon wines. Potravinárstvo, 10(1), 2016, 89-94. https://dx.doi.org/10.5219/534

BAJČAN, D., ÁRVAY, J., VOLLMANNOVÁ, A., BYSTRICKÁ, J., TREBICHALSKÝ, P., HARANGOZO, L', ŠIMANSKÝ, V. 2017. Antioxidan properties, total phenolic and total flavonoid content of the Slovak white wines Welschriesling and Chardonnay. Potravinárstvo, 11(1), 2017, 266-271. doi https://dx.doi.org/10.5219/730

BARHÉ, T.A., TCHOUYA, G.R.F. 2016. Comparative study of the anti-oxidant activity of the total polyphenols extracted from Hibiscus Sabdariffa L., Glycine max L. Merr., yellow tea and red wine through reaction with DPPH free radicals $\begin{array}{llll}\text { Arabian Journal of Chemistry, } & 9(1), & 1-8\end{array}$ https://doi.org/10.1016/j.arabjc.2014.11.048

BERLI, F., D’ANGELO, J., CAVAGNARO, B., BOTTINI, R., WUILLOUD, R. SILVA, M. F. 2008. Phenolic compo-sition in grape (Vitis viniferal. cv. malbec) ripened with different solar Uv-B radiation levels by capillary zone electroforesis. J. Agr. Food Chem., 56, 2892-2898.

BRAND-WILLIAMS, W., CUVELIER, M. E., BERSET, C. 1995. Use of a free radical method to evaluate antioxidant activity. Lebensmittel Wissenschaft und Technologie, 28, 25-30. http://dx.doi.org/10.1016/s0023-6438(95)80008-5 BYSTRICKÁ, J., MUSILOVÁ, J., TOMÁŠ, J., VOLLMANNOVÁ, A., LACHMAN, J., KAVALCOVA, P. 2014. Changes of Polyphenolic Substances in the Anatomical Parts of Buckwheat (Fagopyrum esculentum Moench.) during Its Growth Phases. Foods. 3(4), 558-568. https://doi.org/10.3390/foods3040558 CHANG, C.C., YANG, M.H., WEN, H.M., CHERN, J.C. 2002. Estimation of total flavonoid content in propolis by two complementary colometric methods. Journal of Food and Drug Analysis, 10(3), 178-182.

CHIRCU BRAD, C., MUSTE, S., MUDURA, E., BOBIS, O. 2012. The content of polyphenolic compounds and antioxidant activity of three monovarietal wines and their blending, used for sparkling wine production. Bulletin UASVM serie Agriculture, 69(2), p. 222-227. http://dx.doi.org/10.15835/buasvmcn-agr:8764 EFTIMOVÁ, Z. 2016. Polyphenols content and antioxidant activity of the Tokaj wines and essences. Diploma thesis. Nitra: SUA, 2016, $77 \mathrm{p}$

EVANS, J.L. 2007. Antioxidants: do they have a role in the treatment of insulin resistance? Indian J. Med. Res., 125, 355-372.

FARKAŠ, J. 1983. Biotechnológia vína. Bratislava: Alfa, 984 p.

FIKSELOVÁ, M., KAČÁNIOVÁ, M., MELLEN, M. 2010. Antioxidan (antiradical) and antimicrobial (antifungal) efects of Slovak Tokaj wines. Acta Alimentaria, 39(3), 256-264. https://doi.org/10.1556/AAlim.39.2010.3.2

FELŠÖCIOVÁ, S., RYBÁRIK, L., TANČINOVÁ, D., MAŠKOVÁ, Z., KAČÁNIOVÁ, M. 2015. Microfungi and mycotoxins of grapes from Tokaj wine $\begin{array}{llll}\text { region. } & \text { 4(special issue), } & \text { 16-18 }\end{array}$ https://doi.org/10.15414/jmbfs.2015.4.special1.16-18

GUERCI, B., BOHME, P., KEARNEY-SCHWARTZ, A., ZANNAD, F. DROUIN, P. 2001. Endothelial dysfunction and type 2 diabetes. Diabetes Metab., 27, 436-447.

JACKSON, R.S. 2014. Botrytis. In BATT, C.A., TORTORELLO, M.L. Encyclopedia of food microbiology.Academic Press, 2nd ed., 288-296. ISBN: 978-0-12-384733-1 733-1. http://dx.doi.org/10.1016/b978-0-12-384730$0.00042-2$ 
KING, R. E., BOMSER, J. A., MIN, D. B. 2006. Bioactivity of resveratrol. Comprehensive reviews. Food Science and Food Safety, 5(3), 2006, p. 65-70. https://doi.org/10.1111/j.1541-4337.2006.00001.X

LI, H., WANG, X., LI, Y., LI, P., WANG, H. 2009. Polyphenolic compounds and antioxidant properties of selected China wines. Food chemistry, 112(2), p. 454-460. http://doi.org/10.1016/j.foodchem.2008.05.111

LUGASI, A., HOVARI, J. 2003. Antioxidant properties of commercial alcoholic and nonalcoholic beverages. Nahrung 47, 79-86. https://doi.org/10.1002/food.200390031

MA, T.T., SUN, X.Y., GAO, G.T., WANG, X.Y., LIU, X.Y., DU, G.R., ZHAN, J.C. 2014. Phenolic Characterisation and Antioxidant Capacity of Young Wines Made From Different Grape Varieties Grown in Helanshan Donglu Wine Zone (China). South African Journal of Enology and Viticulture, 35(2), p. 321-331. http://dx.doi.org/10.21548/35-2-1020

MARFAK, A., 2003. Radiolyse gamma des flavonoides: Étude de leur réactivité avec les radicaux issus des alcools: formation des depsides. Thése de doctorat de l'université de Limoges, 220 p.

MINUSSI, R. C., ROSSI, M., BOLOGNA, L., CORDI, L., ROTILIO, D., PASTORE, G. M., DURAN, N. 2003. Phenolic compounds and total antioxidan potential of commercial wines. Food Chemistry, 82, p. 409-416. http://dx.doi.org/10.1016/j.ijfoodmicro.2013.11.008

PIETTA, P. G. 2000. Flavonoids as antioxidants. J. Nat. Prod., 63, 1035-1042. http://dx.doi.org/10.1021/np9904509

SANTOS-BUELGA, C., SCALBERT, A. 2000. Proanthocyanidins and tannin like compounds nature, occurrence, dietary intake and effects on nutrition and health. Journal of the Science of Food and Agriculture, 80(7), 2000, p. 1094 1117. $\quad$ https://doi.org/10.1002/(sici)1097-0010(20000515)80:7<1094::aidjsfa569>3.0.co;2-1

SATO, M., RAMARATHNAM, N., SUZUKI, Y., OHKUBO, T., TAKEUCHI, M., OCHI, H. 1996. Varietal differences in the phenolic content and superoxide radical scavenging potential of wines from different sources. Journal of Agricultural and Food Chemistry, 44, 37-41. http://dx.doi.org/10.1021/jf950190a SINGLETON, V.L., ROSSI, J.A. 1965. Colorimetry of total phenolics with phosphomolybdic-phosphotungstic acid reagents. American Journal of Enology and Viticulture, 16, 14-158.

STAŠKO, A., POLOVKA, M., BREZOVÁ, V., BISKUPIČ, S., MALÍK, F. 2006. Tokay wines as scavengers of free radicals (an EPR study). Food Chemistry, 96, 185-196. https://doi.org/10.1016/j.foodchem.2005.02.022

TIMORACKÁ, M. 2010. Polyphenolic substances. Biology, ecology, chemistry, $14,10-14$.

TOREL, J., CILlaRD, J., CILlARD, P. 1986. Antioxidant activity of flavonoids and reactivity with peroxy radical. Phytochemistry, 25(2), 383-385. https://doi.org/10.1016/S0031-9422(00)85485-0 